\title{
A weighty issue
}

\section{Eduardo Chillida's sculptures are a form of 'rebellion' against Newton.}

\section{Stefano Grillo}

Spanish artist Eduardo Chillida (1924-2002) used the name Gravitation for a major series of works that occupied him over a span of nearly 15 years a clear suggestion that he shared some of the concerns of physical scientists. Indeed, Chillida himself once declared that he used "weight in his sculpture in order to rebel against Newton". Was this simply a fashionably extravagant statement?

No one would claim that Chillida's sculptures and reliefs supersede Isaac Newton's theory of gravitation in the sense that Einstein's general theory of relativity does. Chillida's aim was never to create a new quantitative model to compete with that of Newton. But his statement acquires significance when seen in terms of his work's visual approach to the experience and understanding of nature. This approach consists, in the words of the Nobel-prizewinning poet Octavio Paz, of a "qualitative physics", springing from a "direct, dynamic and non-quantitative vision of reality".

Chillida's works allow one to visually grasp phenomena such as weight, and even its opposite, weightlessness or levitation. He achieves this chiefly through his sense of form and of space. His rhythmically twisting shapes, often supported in ways that defy our visual expectations, seem to possess a weight that is modulated by their form and is quite independent of the measurable properties of the piece. Thus Chillida's great steel and concrete structures often appear to be floating in the surrounding space, whereas the paper reliefs of his Gravitation series communicate a remarkable sense of visual consistency.

In the steel sculpture shown here, De Música III - one of 45 being exhibited at the Yorkshire Sculpture Park in Wakefield, UK, until 4 May (www.ysp.co.uk) - the horizontal structure hovers above the ground in an apparent state of levitation. Our immediate reaction is surprise that there are no additional legs to provide convincing support. The realization of the structure was a remarkable creative and technical achievement. Chillida spent

explicitly beyond the reach of Cambridge's influential colleges.

The Lucasian professor was to lecture for one hour each week, deposit a transcript in the library, and hold office for a further two hours. It may have been at the request of the second incumbent, Isaac Newton, that King Charles II amended the statutes to allow a professor to hold a concurrent college fellowship and to require "all undergraduates past the second year and all Bachelors of Arts up to the third year" to attend the chair's lectures. The first Lucasian professor, Isaac Barrow, vacated the chair in favour of his pupil Newton, who has cast a long shadow over his 15 successors.

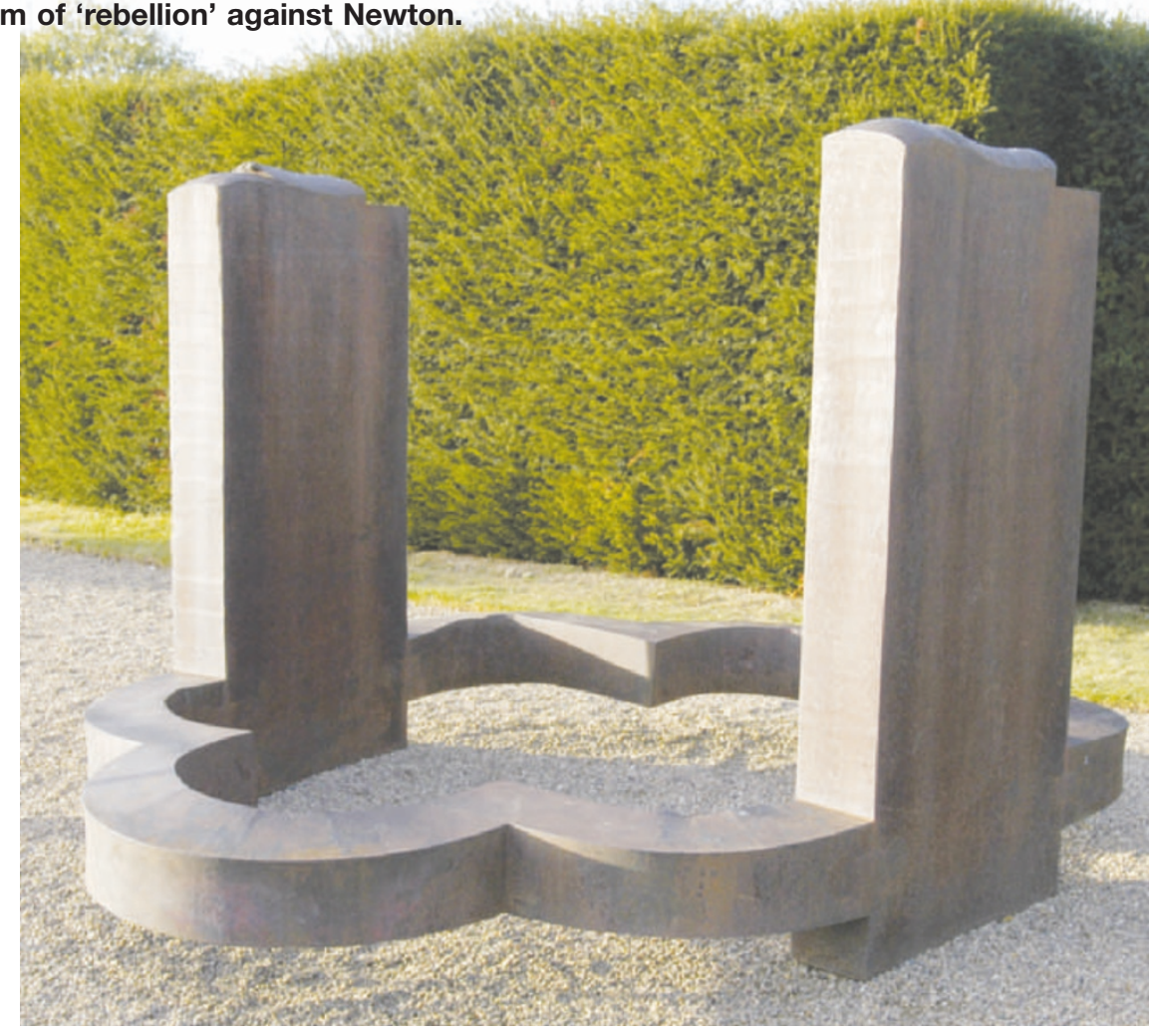

Up in the air: the floating form of De Música III challenges our visual expectations.

several months welding together the unsupported horizontal sections to ensure that the joints were stable enough.

The importance of this visual and non-quantitative way of experiencing reality has been stressed in recent years by the mathematician René Thom, a Fields medallist and admirer of Chillida's work. Thom noted that there are contexts in which nuclear physicist Ernest Rutherford's claim that "qualitative is nothing but poor quantitative" does not hold true. Thom's own field of topology, for example, essentially relies on qualitative distinctions.

It is also significant that Chillida provided the lithocollages to illustrate the book Die Kunst und

The sociologist Max Weber observed that, at least for the papal succession, the second-best candidate generally wins elected office. For much of the history of the Lucasian chair, even second best would be a stretch. Talent circulated freely in eighteenth-century Europe, but the Hanoverian regents hardly gave so much as a thought to looking for a Lucasian professor at GeorgAugust University in Göttingen or, closer to hand, in the great intellectual reservoir of Scotland, home to subtle minds from Colin Maclaurin to the historian and mathematician Thomas Carlyle.

Foreign musicians George Frederick Handel and Joseph Haydn created extraordi- der Raum by the philosopher Martin Heidegger, who was concerned throughout his life with the foundations of modern science and with the question of whether the mathematical approach is the only valid way of understanding physical reality.

So despite Chillida's declared rebellion against newtonian physics, his work has been concerned with grasping the same phenomena in the natural world that have always interested scientists. And the result of his approach is both strikingly spectacular and thought-provoking.

Stefano Emilio Grillo is a physicist at the University of Perpignan and IMP-CNRS, Rambla de la Thermodynamique, Tecnosud, 66100 Perpignan, France.

nary scores in England. A. W. Hofmann brought organic chemistry to London from Germany. Any one of the Bernoullis, Leonhard Euler or Carl Friedrich Gauss would have dramatically changed the course of history had the Lucasian electors been passionate about promoting mathematical talent. Not at Cambridge. The Lucasian professors have all been English or Irish Protestant even the one foreign national, Paul Dirac, a naturalized Briton when he received the chair in 1932, was born in Bristol.

Carlyle described the eleventh Lucasian professor, Charles Babbage, as "a mixture of craven terror and venomous-looking vehemence". Indeed, there is a quirky quality to 